\title{
SEBUAH RUANG UNTUK KOMUNITAS SAMPAH PLASTIK DI MURIA RAYA, JAKARTA
}

\section{SELATAN}

\author{
Audrey $^{1)}$, Rudy Surya ${ }^{21}$ \\ 1)Program Studi S1 Arsitektur, Fakultas Teknik, Universitas Tarumanagara, audrey17satria@gmail.com \\ 2) Program Studi S1 Arsitektur, Fakultas Teknik, Universitas Tarumanagara, rudys@ft.untar.ac.id
}

\begin{abstract}
Abstrak
Sampah plastik yang pengolahannya belum maksimal menjadi masalah ekologis yang cukup berat karena unsur plastik sendiri yang lama terurai. Dari masalah tersebut, didapatkan ide untuk melakukan sebuah kolaborasi dengan komunitas sampah plastik untuk melampaui ekologi menuju arsitektur untuk kebaikan dan kehidupan. Kolaborasi ini diharapkan mampu mengubah persepsi masyarakat akan sampah plastik, sehingga dapat memotivasi gerakan daur ulang sampah plastik. Kolaborasi komunitas ini terdiri dari komunitas pengumpul, komunitas kreatif, dan komunitas penduli lingkungan, dengan bentuk pengumpulan bahan baku dalam material sampah yang siap diolah menjadi produk furniture/kerajinan oleh komunitas kreatif, serta tambahan untuk mendukung gerakan peduli lingkungan. Metode yang digunakan pada proyek ini adalah kontekstual, dengan menyelaraskan nilai-nilai karakteristik terhadap lingkungan sekitar terutama pada isu yang diangkat, yaitu sampah plastik terhadap program dan tempat; bentuk bangunan; bahan dan sistem bangunan. Konsep yang diterapkan adalah upcycle, di mana material yang digunakan adalah material daur ulang sehingga para penggiat kreatif dapat berkumpul dan bekerja sama untuk menghasilkan produk. Proyek Ruang Kolaborasi Komunitas Sampah Plastik menjadi wadah bagi antar silang komunitas untuk dapat mengurangi jumlah sampah plastik dengan prinsip melampaui ekologi, mengubah terapan 3R (Reduce, Reuse, Recycle) menjadi 4R + 1U (Reduce, Reuse, Rethink, Upcycle, Replace). Kelompok kegiatan daur ulang dibagi menjadi 3 ruang berdasarkan kebutuhan bagi masing-masing penggiat kreatif (furniture, seniman, dan penjahit) serta diharapkan proyek ini mampu menyadarkan kembali masyarakat terkait pemanfaat sampah plastik yang bisa menjadi bagian kehidupan.
\end{abstract}

\section{Kata kunci: Sampah; Plastik; Komunitas; Upcycle; Recycle}

\begin{abstract}
Plastic waste processing has not been maximized. The plastic elements themselves that take a long time to decompose causes a trap for the ecology. From this problem, an idea was obtained to collaborate with the plastic waste community for beyond ecology to architecture for goodness and life. Meanwhile, community collaboration will be a new hope that can turn plastic waste into a part of life with the encouragement of plastic waste recycling and public awareness. The method used in this project is contextual, by aligning characteristic values with the surrounding environment, especially based on issue, Plastic Waste - programs and places; building form; building materials and systems. The applied concept is upcycle, where the material used is recycled material, so creative activists can gather and work together to produce products. The recycling activity group is divided into 3 rooms based on the needs of each creative activist (furniture, artists \& tailors). It is hoped that this project will be able to re-awaken the public regarding the use of plastic waste that can be a part of life. Collaboration Space for Plastic Waste Community project is a forum for cross-community to be able to reduce the amount of plastic waste waste with the principle of going beyond ecology such as changing the application of $3 R$ (Reduce, Reuse, Recycle) to $4 R+1 U$ (Reduce, Reuse, Rethink, Upcycle, Replace). In other words, community collaboration is obtained from the collecting community, the creative community, and the community which care about the environment by collecting raw materials in waste materials that are ready to be processed into furniture/craft products by the creative community, as well as additional support for the environmental care movement.
\end{abstract}

\section{Keywords: Waste; Plastic; Community; Upcycle; Recycle}




\section{PENDAHULUAN}

\section{Latar Belakang}

Manusia sebagai makhluk hidup merupakan ekosistem yang bersuksesi dan ingin hidup stabil dan mencapai kebutuhan hidupnya. Laju pertambahan jumlah penduduk dan meningkatnya kebutuhan menyebabkan lingkungan ikut terdampak (Effendi, Salsabila, \& Malik, 2018). Semua berakar pada perilaku manusia, seperti pola produksi dan konsumsi yang sangat eksesif dan tidak ekologis, semua teknologi yang ditemukan oleh manusia cenderung untuk merusak lingkungan baik secara langsung maupun tidak (Satmaidi, 2015). Secara estimologis, istilah "Ekologi" berasal dari Bahasa Yunani, yaitu "oikos" yang artinya rumah/tempat untuk hidup dan "logos" yang artinya ilmu. Sehingga ekologi dapat diartikan sebagai ilmu yang mempelajari tentang hubungan antara makhluk hidup/tentang ekosistem dengan lingkungan hidupnya.

Dampak dari perilaku manusia ini bisa dilihat pada jumlah sampah. Sampah muncul dari sifat konsumtif manusia. Sampah merupakan material sisa yang sudah tidak digunakan lagi oleh manusia sehingga dibuang (Elamin, et al., 2018). Sampah memerlukan solusi yang lebih dari sekedar membuang sampah pada tempatnya. Indonesia saat ini menempati posisi kedua sebagai negara penyumbang sampah terbesar di dunia setelah Cina (Kompas, 2016). Pertumbuhan kota dan penambahan jumlah penduduk menyebabkan peningkatan aktivitas (jasa, industri dan bisnis) yang berdampak pada meningkatnya sampah dari aktivitas. Peningkatan sampah ini menjadi persoalan terhadap ekologi.

Jakarta menjadi salah satu contoh kota yang memiliki persoalan sampah, terutama pada penanganan dan ketersediaan sarana dan prasarana untuk pengolahan sampah (Winahyu, Hartoyo, \& Syaukat, 2013). Tempat Pembuangan Sampah Terpadu (TPST) Bantargerbang menjadi salah satu yang terkena dampak yang mengalami pemenuhan karena produksi sampah yang terus meningkat (Hamzah, 2016). Selain itu timbunan sampah di setiap daerah yang ada di Jakarta masih belum terolah dengan baik. Padahal timbunan sampah ini menjadi perangkap ekologis di lingkungannya. Karena memiliki resiko bagi sekitarnya, salah satunya adalah plastik, yang lama terurai.

Untuk mengatasi permasalahan tersebut, saat ini oleh pemerintah sudah disediakan tempat pengelolaan sampah Reduce, Reuse, Recycle (TPS3R) dan bank sampah serta kebijakan baru yang melarang penggunaan plastik (2020), tetapi solusi ini masih belum bisa mendorong upaya meminimalisasi sampah (Ardhani \& Pongtuluran, 2020). Selain dari pemerintah, ada juga dari komunitas sampah, seperti fasilitas setor sampah anorganik (waste4change, rekosistem dan armada kemasan), gerakan gaya hidup (zerowaste) \& daur ulang sampah menjadi material bangunan (rebricks.id) yang untuk saat ini sudah mendorong upaya meminimilisasi sampah. Solusi-solusi ini nyatanya masih belum berhasil, karena kesadaran masyarakat masih kurang serta sarana dan prasarana masih kurang (Hendra,2016).

\section{Rumusan Permasalahan}

Dari uraian latar belakang masalah diatas, diuraikan beberapa pertanyaan sebagai berikut :

a. Apa peran arsitektur dalam memberikan solusi dalam melampaui ekologi menuju arsitektur untuk kebaikan dan kehidupan?

b. Arsitektur seperti apa yang mampu memberikan jawaban permasalahan sampah plastik terhadap ekologi kehidupan umat manusia di perkotaan seperti Jakarta?

\section{Tujuan}

Tujuan proyek ini adalah untuk menjawab tantangan permasalahan sampah plastik di Jakarta yang jumlahnya semakin meningkat, dan diharapkan mampu mengubah persepsi masyarakat akan sampah plastik, sehingga dapat memotivasi gerakan daur ulang sampah plastik dan menyadarkan kembali bahwa sampah plastik bisa menjadi bagian dari kehidupan. dengan mengolah sampah plastik menjadi produk yang lebih bermutu seperti perabotan, pakaian dan kreasi seni. 


\section{KAJIAN LITERATUR}

\section{Ekologi}

Ekologi pertama kali dicetuskan oleh Ernest Haeckel, 1869 adalah "ekologi adalah ilmu yang mempelajari hubungan timbal balik (interaksi) antara organisme dengan alam sekitar atau lingkungannya" (Maknun, 2017). Selain itu oleh Ken Yeang (2010) "Ecology Study of the structure and function of nature; the relationship between organisms and their environment."

\section{Melampaui Ekologi/Beyond Ecology}

Beyond ecology tidak lagi berbicara pada ranah ekologi dengan batas biologi semata, akan tetapi berbicara sebagai sistem yang terhubung, terkait dan berinteraksi (interrelation, interconnectivity and interaction) antara berbagai komponen baik alam, biotik maupun abiotik pada berbagai skala dan kompleksitas. Beyond ecology adalah suatu sistem biologi yang digunakan untuk menyelesaikan atau melihat atau menganalisis suatu fenomena non biologi (Winata, 2021).

Oleh Agustinus Sutanto Dalam kuliah tamu Dromos Oikos (2021), dalam melampaui ekologi, pada pembangunan diperlukan adanya acuan/parameter dalam menghadapinya, di antaranya ada :

a. Energi dan Emission

Kemampuan menerapkan zero $\mathrm{CO} 2$ emission dalam pengoperasionalan bangunan dan meminimalisasi efek karbon dalam material dan konstruksi.

b. Adaptation

Kemampuan untuk melakukan riset dan desain yang berkaitan dengan berbagai dampak, seperti naiknya suhu bumi, naiknya permukaan laut, kekeringan, banjir, kelangkaan pangan, perubahan populasi.

c. Resilience

Kemampuan untuk membangun kelanjutan hunian dan pemulihan cepat setelah kejadian guncangan, bencana alam, gangguan listrik atau iklim.

d. Sustainable Digital

Kemampuan untuk melihat data-data lingkungan sebagai Big Data dalam menentukan taktik dan strategi dalam membangun kualitas spasial.

e. New technology

Kemampuan memanfaatkan teknologi terbaru untuk meningkatkan kualitas terapan ruang konstruksi dan program bangunan.

f. Context

Kemampuan dalam melihat posisi tempat dalam hubungan dengan lingkungan (flora-fauna, biotic-abiotic) di mana sebuah konfigurasi keruangan akan ditempatkan.

\section{Ekosistem Sampah}

Tempat pembuangan sampah bisa menjadi sumber racun atau perangkap ekologis, karena dapat menarik hewan sehingga menyebabkan kerusakan jangka Panjang pada populasi hewan. (Plaza \& Lambertucci, 2017)Salah satunya sampah plastik juga mempengaruhi ekosistem laut, berdasarkan sekelompok peneliti Austria yang telah menemukan bukti bahwa mikroplastik, potongan, fragmen, dan serat plastik ternyata terakumulasi pada kotoran manusia. Artinya, setelah hewan laut memakan sampah plastik, manusia kemudian ikut menelannya melalui tuna, udang, atau lobster, dll. (Widyaningrum, n.d.)

\section{Sampah Plastik}

UU No 18 Tahun 2008 tentang Pengelolaan Sampah, disebutkan sampah adalah sisa kegiatan sehari hari manusia atau proses alam yang berbentuk padat atau semi padat berupa zat organik atau anorganik bersifat dapat terurai atau tidak dapat terurai yang dianggap sudah tidak berguna lagi dan dibuang kelingkungan. 
Plastik merupakan produk serbaguna, ringan, fleksibel, tahan kelembaban, kuat, relatif murah. Karena berbagai kemudahan tersebut, seluruh dunia bernafsu untuk menghasilkan lebih banyak produk berbahan baku plastik. Namun, tanpa disadari, karakter dasar plastik, ditambah cara penggunaan yang tidak ramah lingkungan, ia justru merusak lingkungan hidup. Plastik adalah sampah yang tidak dapat langsung terurai, bahkan membutuhkan waktu ratusan tahun lamanya. Terdapat dua tipe plastik.

a. Thermoset, yaitu plastik yang polimer penyusunnya terikat secara permanen, sehingga tidak dapat berubah saat sudah terbentuk atau mengeras saat suhu dingin (tidak dapat mencair maupun didaur ulang).

b. Thermoplastic, yaitu plastik polimer yang mengeras saat suhu rendah dan mencair saat suhu tinggi (dapat didaur ulang).

Delapan puluh persen plastik di dunia merupakan thermoplastic (Winnerdy dan Laoda, 2020). Plastik tipe ini dibagi-bagi lagi berdsarkan struktur dan propertinya dan ditandai dengan nomor yang dicetak pada permukaan materialnya dengan urutan sebagai berikut (Arah Environment,2015):

a. Polyethlene Terephthalate (PET)

PET biasanya terdapat pada kemasan botol minuman ringan. PET juga terdapat pada wadah toples untuk selai atau makanan cepat saji. Tipe plastik ini biasanya dapat digunakan untuk makanan yang bisa dihangatkan dalam oven dan microwave. Secara umum PET merupakan jenis yang aman bagi manusia.

b. High Density Polyethylene (HDPE)

HDPE biasanya digunakan pada kosmetik dan bahan pembersih rumah tangga. HDPE merupakan plastik dengan tingkat bahaya yang rendah. Bahan kimia yang memiliki estrogenik aktif (EA) diduga dapat menyebabkan masalah kesehatan terutama pada janin dan anak-anak. Paparan EA dapat mengubah struktur sel manusia. Paparan EA tersebut dapat terjadi ketika plastik terkena air mendidih, sinar matahari (UV), dan pemanasan microwave.

c. Polyvinyl Chloride (PVC)

Bahan plastik ini biasanya dipakai untuk produksi kemasan wadah obat-obatan. PVC merupakan plastik yang cukup berbahaya.

d. Low Density Polyethylene (LDPE)

Jenis plastik ini dapat ditemukan pada bungkus roti, makanan beku, pelapis kertas kotak susu, dan cup untuk minuman dingin atau panas. LDPE juga digunakan untuk membuat wadah penutup, seperti mainan dan botol yang dapat dipencet (seperti untuk madu dan saus mustard). LDPE merupakan plastik dengan tingkat bahaya yang rendah.

e. Polypropylene (PP)

PP biasa terdapat pada wadah yogurt, margarin, dan bungkus makanan siap saji. Jenis ini juga ditemukan pada botol obat-obatan, tutup botol, dan botol untuk saus tomat dan sirup. PP merupakan jenis plastik yang aman.

f. Polystyrene (PS)

Polystrene disebut juga styrofoam, umum ditemukan pada wadah makanan seperti cup, piring, dan mangkuk. Meskipun sangat rendah, styrene nyatanya juga diketahui sebagai penyebab tumor paru-paru dalam sebuah percobaan pada seekor tikus.

g. Plastik 7 (Other)

Plastik 7 atau yang dikenal dengan sebutan other ini terdapat pada botol saus, bumbu, botol makanan bayi, gelas anak-anak, botol air minum, galon air isi ulang, dan kemasan bea cukai. Plastik tipe ini dapat termasuk polycarbonate yang mengandung bahan kimia bisphenol $A$ (BPA). BPA dapat mengkontaminasi makanan ketika dicuci untuk digunakan kembali.

\section{Upcycling}


Upcycling dapat diartikan dengan mengolah kembali produk yang sudah tidak terpakai atau limbah secara kreatif, sehingga bisa digunakan lagi dan mengurangi dampak merusak lingkungan. Upcycling merupakan salah satu cara dari proses recycle, yaitu proses mengubah atau mengekstraksi sebuah bahan atau produk yang sudah tidak dibutuhkan untuk menghasilkan produk atau bahan yang baru dengan nilai dan fungsi yang berbeda. Tujuan konsep upcycling adalah untuk mengurangi pemborosan bahan, dengan memanfaatkan dan mengolahnya dengan baik (Mcdonough \& Braungart, 2002). Hal itu untuk mengejar siklus pemakaian berlanjut atau sustainable, sehingga produk yang dihasilkan bernilai tinggi dan ramah lingkungan. Upcycling memungkinkan adanya perpanjangan siklus hidup suatu produk.

\section{Kolaborasi}

Menurut abdulsyani (1994) Kolaborasi adalah suatu bentuk proses sosial, dimana di dalamnya terdapat aktivitas tertentu yang ditujukan untuk mencapai tujuan bersama dengan saling membantu dan saling memahami aktivitas masing-masing. Di dalamnya melibatkan pembagian tugas, dimana setiap orang mengerjakan setiap pekerjaan yang merupakan tanggung jawabnya demi tercapainya tujuan bersama.

\section{Komunitas}

Mengutip dari salah satu ahli (Ibeng \& Puspito, 2021), merupakan suatu kelompok sosial atau juga kumpulan nyata, teratur, serta tetap dari individu-individu yang melaksanakan peranperannyaitu dengan secara berkaitan untuk dapat mencapai tujuan bersama. Dalam ilmu sosial, komunitas memiliki arti sebagai kelompok dari berbagai organisme yang melakukan kegiatan sosial karena memiliki ketertarikan dan habitat yang sama.

\section{METODE}

Metode yang digunakan dalam perancangan proyek ini adalah metode kontekstual. Kontekstual adalah adaptasi bentuk dengan konteks, berbagai jenis konteks alam, sejarah, psiko-budaya dan buatan manusia dipertimbangkan dan penghargaan terhadap kondisi masa lalu (sebagai kondisi awal) adalah sebuah basis penghotmatan terhadap tradisi yang sudah ada sebelumnya. (Sutanto, 2020)

Diagram usulan baru sebagai pendekatan berpikir kontekstual :

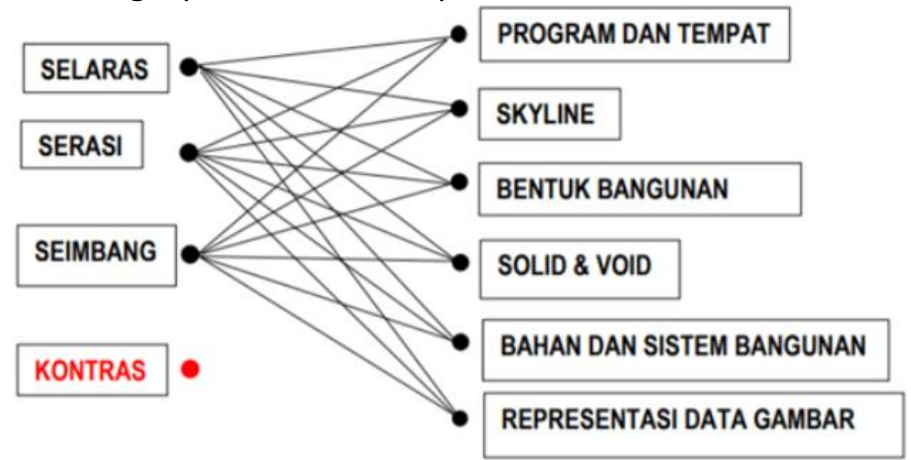

Gambar 1. Pendekatan kontekstual Sumber: Sutanto, 2020

Terkait melampaui ekologi, pendekatan kontekstual diatas menjadi acuan dalam proses mendesain terutama terkait kondisi lingkungan.

\section{DISKUSI DAN HASIL}

\section{Lokasi Tapak}

Lokasi tapak berada di Jl. Muria Raya, RT.17/RW.1, Menteng Atas, Kecamatan Setiabudi, Kota Jakarta Selatan, Daerah Khusus Ibukota Jakarta 12960. Dengan data tapak sebagai berikut :

Luas : $6.037 \mathrm{M}^{2}$ (Jakartasatu)

KDB : $40 \%\left(2.415 \mathrm{M}^{2}\right)$ 
KLB : $1,2\left(7.244 \mathrm{M}^{2}\right)$

$\mathrm{KB}: 5$

$\mathrm{KDH}: 30 \%\left(1.811 \mathrm{M}^{2}\right)$

KTB : 55

Zona : Prasarana Pelayanan Umum

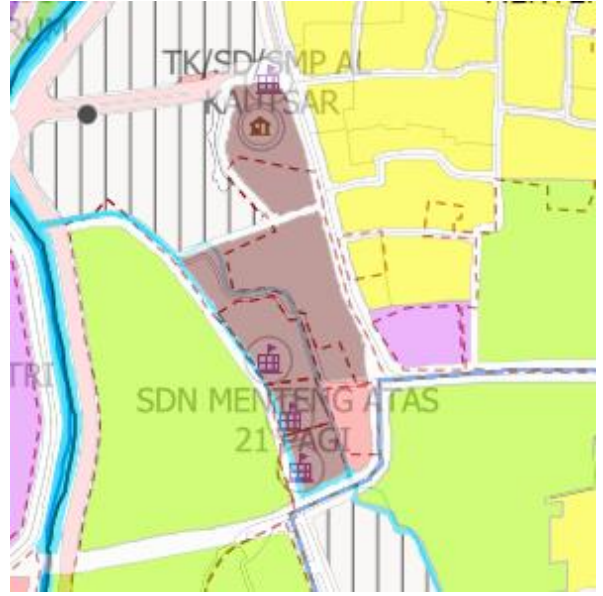

Gambar 2. Peta Lokasi Tapak

Sumber : https://www.google.com/maps

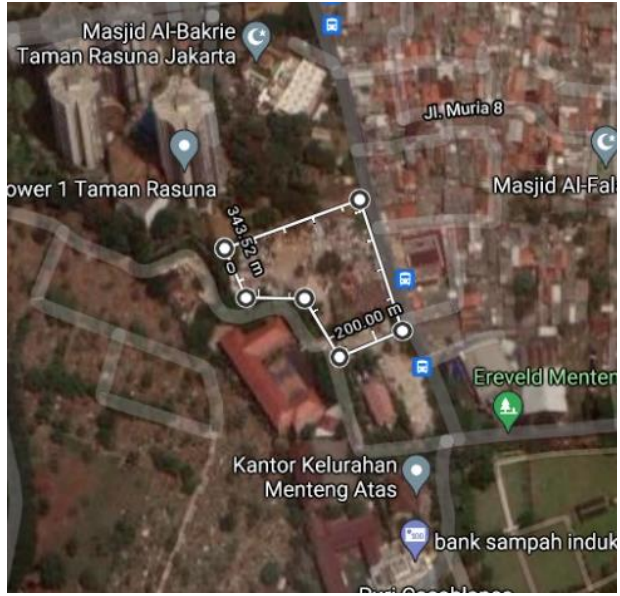

Gambar 3. Peta Zonasi Tapak

Sumber : Jakartasatu.jakarta.go.id

\section{Program}

Program utama dari proyek ini difokuskan pada pengolahan sampah menjadi produk yang diolah menjadi produk yang mempunya nilai tinggi yang dilakukan oleh komunitas kreatif. Dengan bentuk pengumpulan bahan baku dalam material sampah yang sudah siap diolah menjadi produk furniture/kerajinan. Dengan program kegiatan didalamnya ada :

a. Upcycling Space (70\%)

Sebagai wadah kegiatan untuk komunitas kreatif dalam membuat produk hasil daur ulang yang memiliki nilai jual tinggi, diantaranya ada komunitas pembuat furniture (meja, kursi dan perabotan kecil), komunitas penjahit (tas \& karpet), dan komunitas kesenian (instalasi). Dengan kegiatan didalamnya ada melakukan research, pembuatan, dan pemasaran keluar

b. Pengumpulan Sampah (5\%)

Sebagai wadah untuk mengumpulkan sampah oleh pengunjung yang datang, dengan sistem sampah yang dikumpulkan akan disumbang secara sukarela (disediakan tempat dropping berupa tempat sampah), dan sampah yang dikumpulkan nantinya digunakan untuk memberikan edukasi di support lingkungan, untuk kegiatan workshop.

c. Support Lingkungan (25\%)

Sebagai wadah kegiatan untuk komunitas peduli lingkungan untuk memberikan pengenalan tentang sampah plastik dan daur ulangnya (melalui edukasi/workshop dan pameran) kepada pelajar. Serta menjual produk hasil daur ulang kepada pengunjung. Serta dukungan ruang komunal untuk perkumpulan warga 


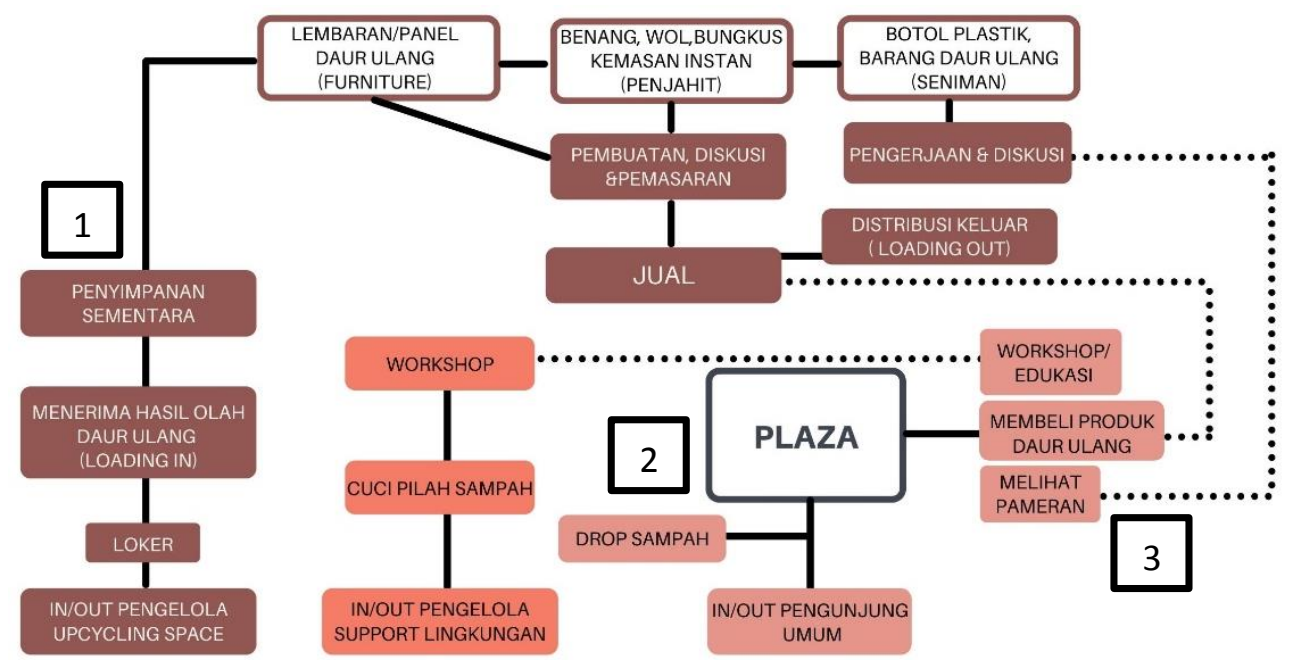

Gambar 4. Alur Kegiatan Program

Sumber: Penulis, 2021

Dengan luas masing-masing program yaitu, upcycling space $1.700 \mathrm{~m}^{2}$, pengumpulan sampah 65 $\mathrm{m}^{2}$, dan support lingkungan $560 \mathrm{~m}^{2}$. Total luasan adalah $2.325 \mathrm{~m}^{2}$.

\section{Zoning Program pada Tapak}

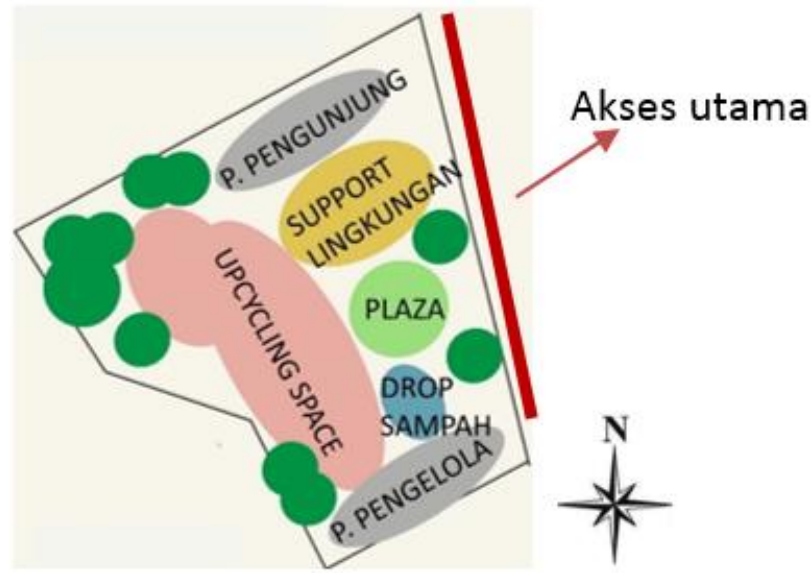

Gambar 5. Zonning tapak

Sumber: Penulis, 2021

Dari respon terhadap program dan analisa tapak, maka ditentukan pembagian zona. Area privat dijadikan sebagai upcycling space dan diletakan di belakang tapak sebagai respon terhadap aktivitas yang dilakukan. Bagian depan dijadikan area publik dan semi publik (drop sampah, plaza dan support lingkungan) untuk menarik pengunjung, dengan dilakukan pemisahan pula akses masuk untuk drop sampah, pemisahan ini dilakukan untuk memisahkan bagi pengunjung yang mau menyumbangkan sampahnya tidak bertabrakan dengan pengunjung yang mau belajar maupun berbelanja di area support lingkungan. Area parkir dipisahkan menjadi dua, sebagai pemisah untuk kegiatan pengguna, yaitu untuk pengelola dan pengunjung, dengan loading barang dipisah terhadap aktivitas daur ulang, Loading in berada di tempat parkir pengelola, dan loading out berada di tempat parkir pengunjung.

\section{Respon Melampaui Ekologi}

Dalam respon untuk melampaui ekologi, maka proyek ini menerapkan prinsip baru dari terapan 3R (Reduce, Reuse, Recycle) menjadi 4R + 1U (Reduce, Reuse, Rethink, Upcycle, Replace). 


\section{R MENJADI 4R + 1 U (BEYOND ECOLOGY)}

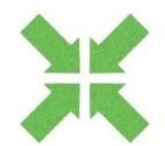

REDUCE

MENGURANG PENUMPUKAN

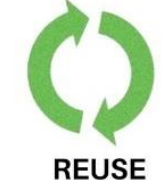

MENGGUNAKAN

KEMBALI

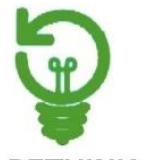

RETHINK

BERPIKIR

KEMBALI

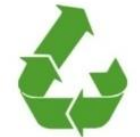

UPCYCLE

MENGOLAH KEMBALI

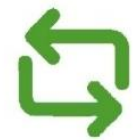

REPLACE

MENGGANTI

Gambar 6. Prinsip baru melampaui ekologi

Sumber: Penulis, 2021

\section{Konsep}

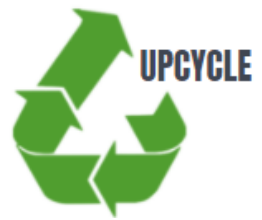

Gambar 7. Upcycle

Sumber : https://www.google.com/

Konsep upcycle diterapkan dalam proses, yaitu dengan cara mengaplikasikan bahan-bahan ramah lingkungan, terutama menggunakan material daur ulang seperti:

a. Material olahan daur ulang campuran dari limbah plastik dan material lain untuk pemasangan pada dinding, lantai, second skin, dan dinding luar untuk support lingkungan.

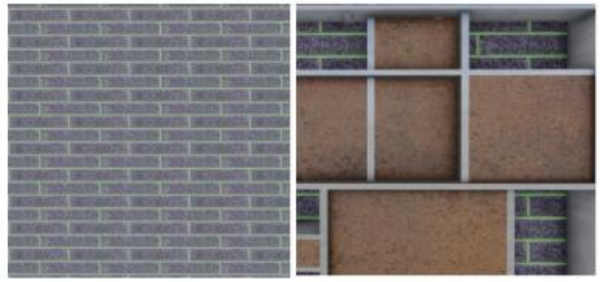

Gambar 8. Material olahan daur ulang Sumber: Penulis, 2021

b. Material bekas yang bisa dipakai seperti keranjang plastik bekas sebagai sekat pemisah ruangan.

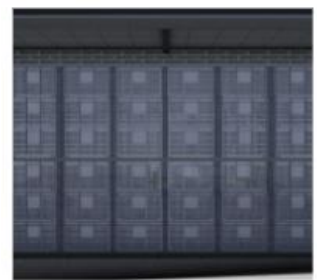

Gambar 9. Material bekas Sumber: Penulis, 2021

Selain itu pendekatan berpikir dalam kontekstual juga diterapkan ke dalam desain, dengan pendekatan melalui :

a. Program dan tempat

Mengambil karakteristik sekitar yang menjadikan area depan rumah sebagai tempat untuk berkomunikasi dengan tetangga, sehingga dibuat ruang plaza didepan sebagai semangat tempat untuk warga. 


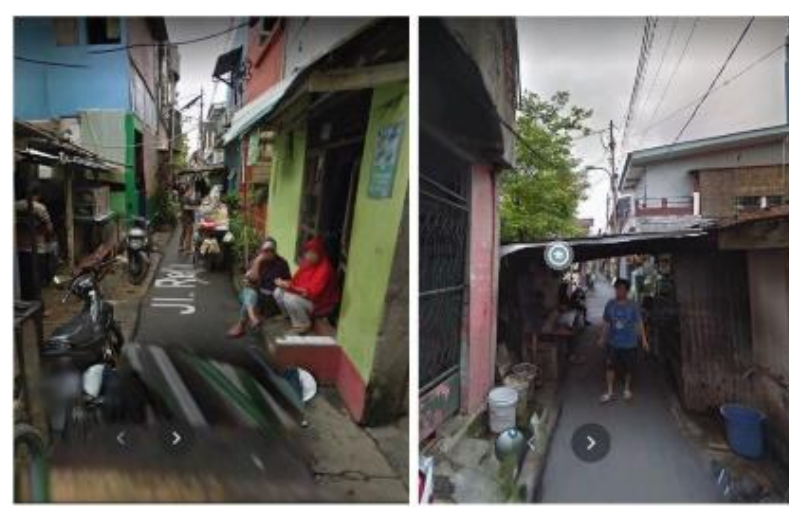

Gambar 10. Kegiatan warga di depan rumah Sumber : https://www.google.com/maps

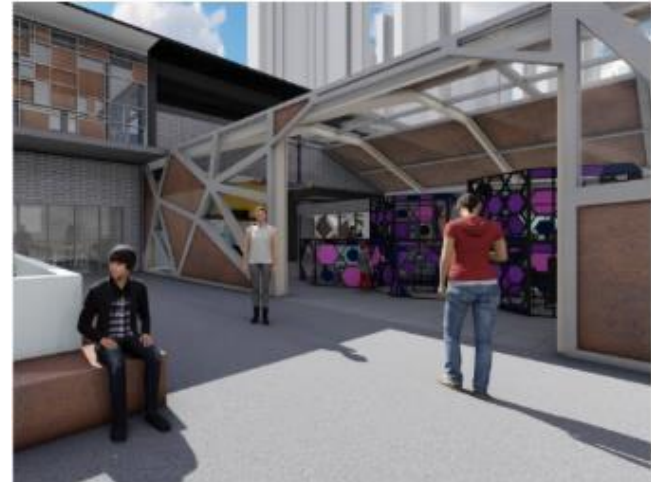

Gambar 11. Plaza

Sumber: Penulis, 2021

b. Bentuk bangunan

Bentuk bangunan sekitar yang menerapkan arsitektur lokal tropis menjadi dasar dalam perancangan. Pada bangunan juga didesain balkon-balkon kecil untuk menambah ruang terbuka pada bangunan, sehingga membentuk lebih dinamis.

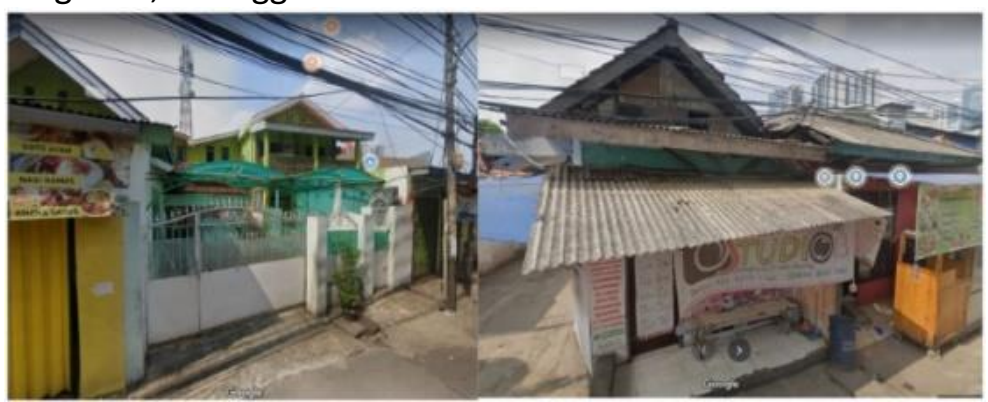

Gambar 12. Bentuk bangunan sekitar Sumber : google maps

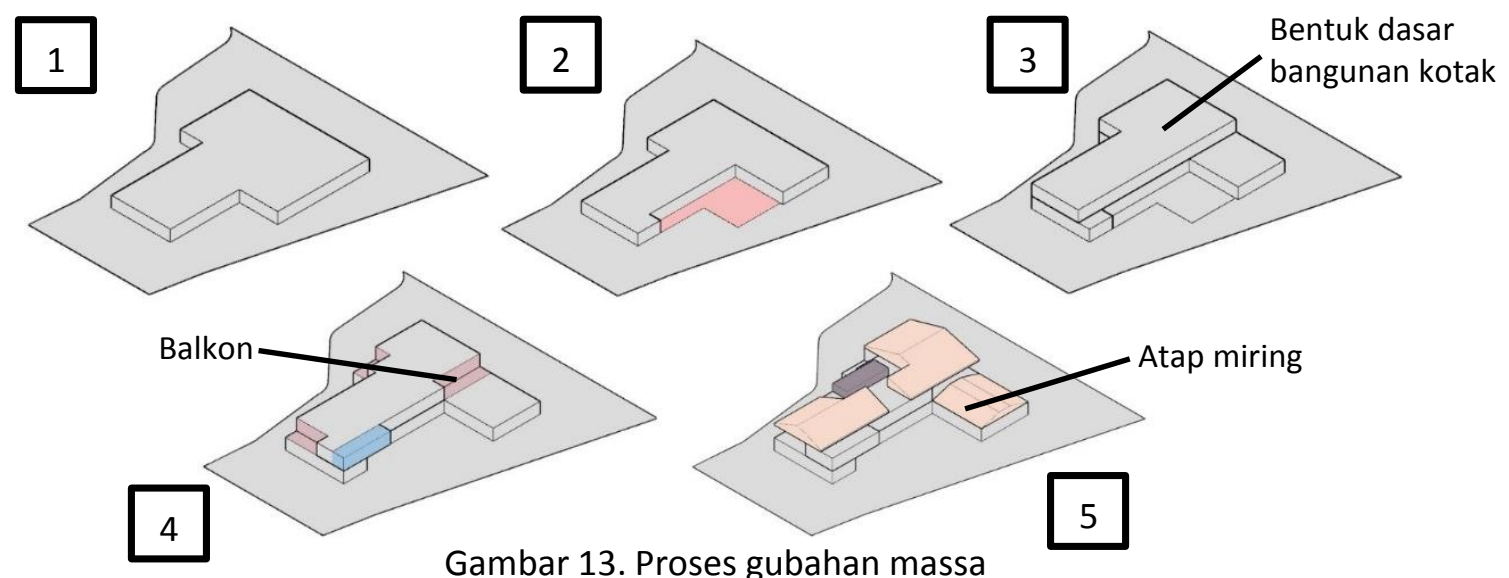
Sumber: Penulis, 2021 


\section{Penerapan Ide Desain pada Bangunan}

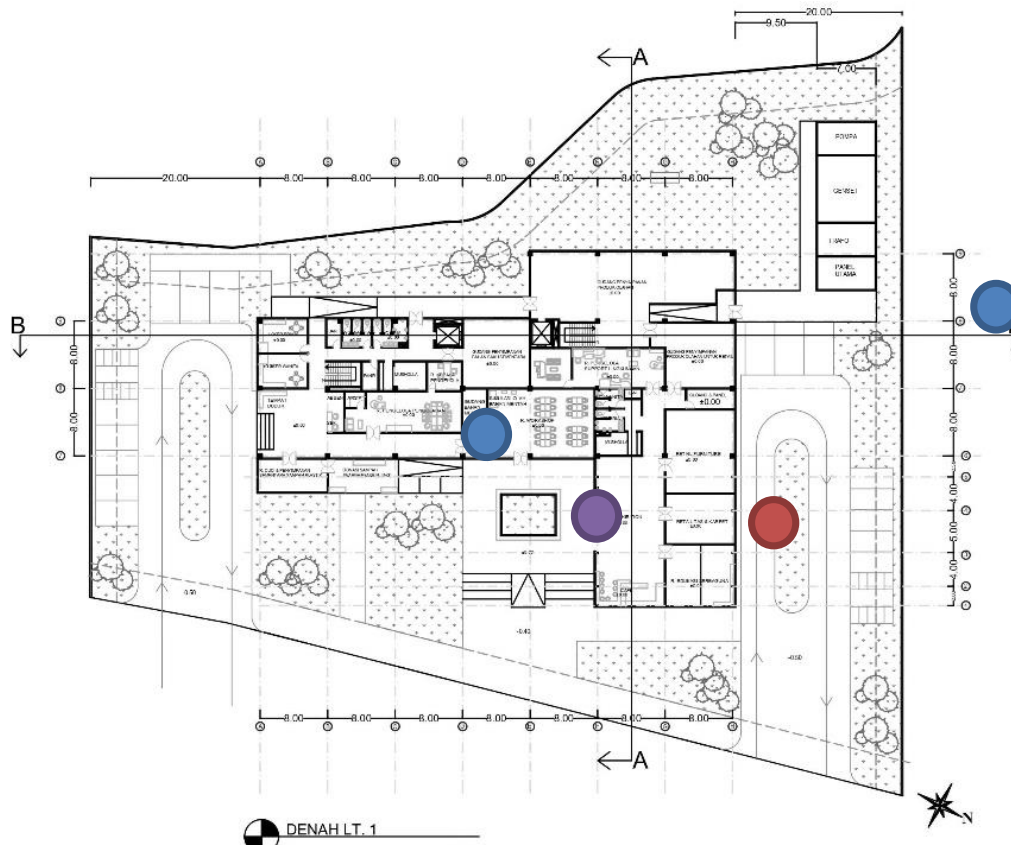

Legenda :

Merah : support lingkungan Ungu : drop sampah

Biru : upcycling space

Gambar 14. Denah Lt. 1

Sumber: Penulis, 2021

Pada lantai 1, akses pada bangunan dibagi menjadi 3, sebagai respon terkait kegiatan didalamnya,area warna biru sebagai upcycling space, kiri untuk loading in bahan baku untuk daur ulang, dan akses masuk dan keluar bagi pekerja. Lalu biru kanan sebagai area untuk loading out produk daur ulang. Pada warna ungu dibuat untuk drop sampah, area tersebut dibuat kecil, karena difokuskan untuk pengunjung yang mau menyumbangkan sampahnya, yang kemudian sampah dibawa ke ruang workshop untuk digunakan sebagai kegiatan belajar melakukan daur ulang. Warna merah menjadi area support lingkungan (exhibition, toko daur ulang, workshop dan edukasi serbaguna).

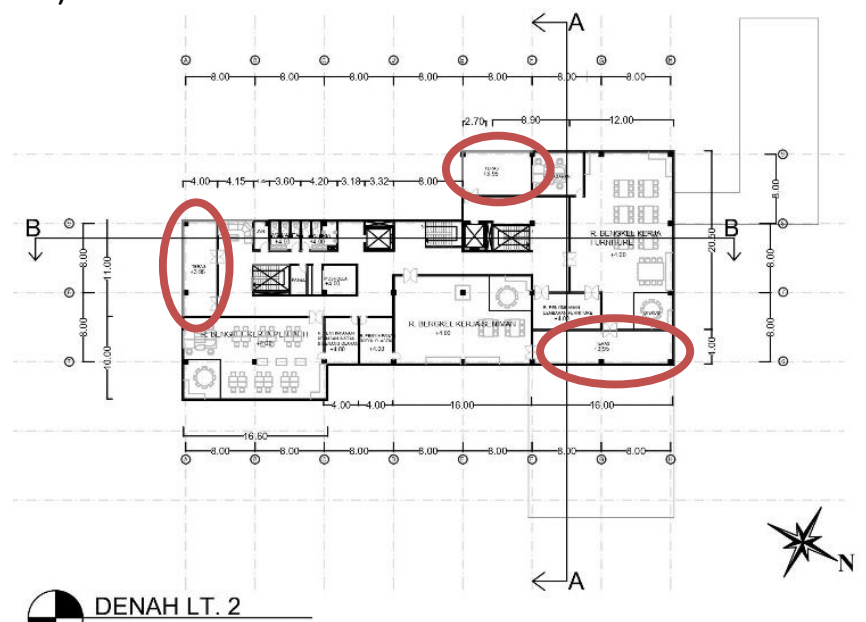

Gambar 15. Denah Lt.2

Sumber: Penulis, 2021

Pada lantai 2 digunakan untuk upcycling space, dengan fokus sebagai ruang bengkel/ruang kerja untuk komunitas kreatif (furniture, seniman, dan penjahit) dengan besaran ruang tergantung pada masing-masing dari kebutuhan ruang untuk kegiatannya. Ide desain juga menciptakan ruang yang lebih dinamis dengan menambahkan balkon pada beberapa sisi bangunan. 


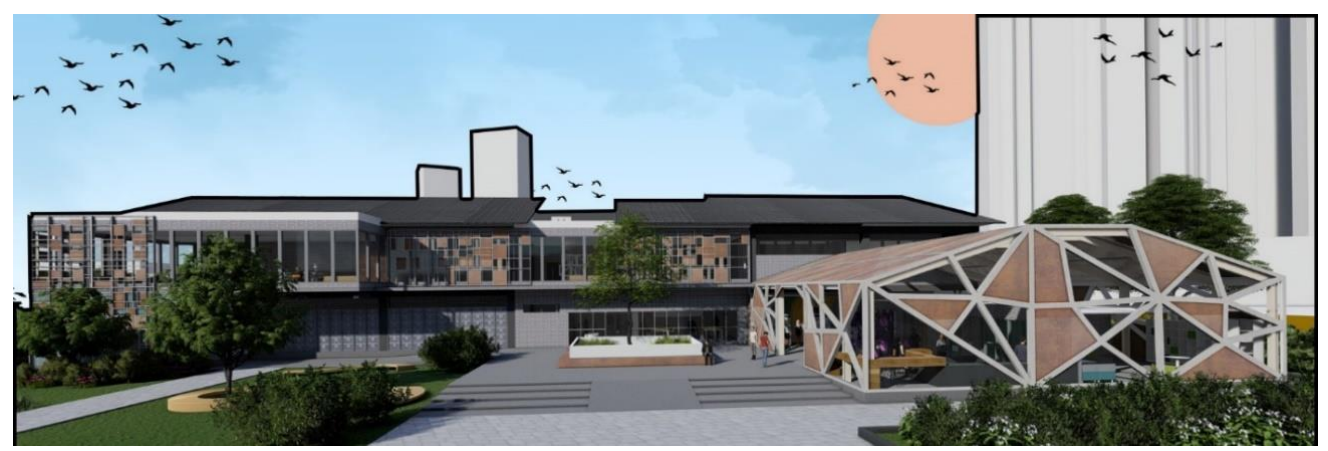

Gambar 16. Perspektif depan

Sumber: Penulis, 2021

Bentuk massa dibuat menjadi 3 bagian,sesuai dengan fungsi yang ada di bawahnya, bagian kiri upcycling space, untuk area loading in bahan baku dan drop sampah, lalu bagian kanan sebagai louding out untuk hasil daur ulang. Untuk bagian depan sebagai support lingkungan.

Desain juga menerapakan penggunaan material daur ulang yaitu, dinding bata dan finishing lantai dari campuran bahan plastik dengan bahan campuran. Lalu untuk second skin dan dinding luar support lingkungan menggunakan rangka hollow dan panel daur ulang botol plastik. Penggunaan jendela low e-glass yang kegunaanya berfokus untuk mendukung bangungan go green ini lebih banyak diletakan pada area kerja di upcycling space dengan respon untuk meminimilasis penggunaan lampu pada saat pengerjaan daur ulang.

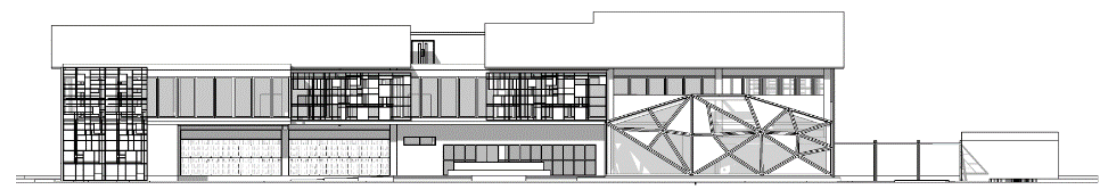

Gambar 17. Tampak depan

Sumber: Penulis, 2021

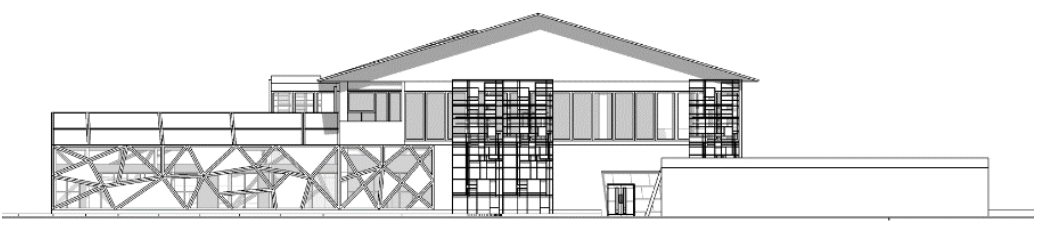

Gambar 18. Tampak samping kiri

Sumber: Penulis, 2021

\section{KESIMPULAN DAN SARAN}

\section{Kesimpulan}

Proyek Ruang Kolaborasi Komunitas Sampah Plastik menjadi respon untuk menjawab tantangan terkait penumpukan sampah plastik yang belum terkelola pengolahannya. Kolaborasi ini menjadi harapan baru yang mampu mengubah persepsi masyarakat akan sampah plastik, sehingga dapat memotivasi gerakan daur ulang sampah plastik dan membuat kita bisa hidup bersama sampah plastik. Proyek ini juga dirancang untuk mencapai tujuan melampaui ekologi dengan menerapkan prinsip baru dari terapan 3R (Reduce, Reuse, Recycle) menjadi 4R $+1 \mathrm{U}$ (Reduce, Reuse, Rethink, Upcycle, Replace) sehingga mampu menjadikan sampah menjadi bagian dari kehidupan.

Dengan menjadikan sampah sebagai harapan baru untuk menjadi bagian dari kehidupan, penelitian terkait pengelolaan sampah perlu dikembangkan lebih lanjut. Perlu dikembangkan studi lebih mendalam terkait hasil dari terapan pada prinsip $4 R+1 U$. Selain itu aspek design terkait penggunaan material daur ulang perlu diperhatikan, sehingga bisa menjadi daya tarik dan bisa mendorong untuk dipakai masyarakat. 


\section{REFERENSI}

Abdulsyani. (1994). Sosiologi Skematika, Teori, dan Terapan. Jakarta: Bumi Aksara

Ardhani, A. D., \& Pongtuluran, Y. A. (2020). Dua Sisi Mata Uang: Kebijakan Publik dan Penanganan Sampah Plasyik di Indonesia. Kementerian Sosial Politik dan Kajian Strategis BEM USD.

Direktorat Pengembangan Penyehatan Lingkungan Pemukiman. (2018). Petunjuk Teknis Penyusunan Studi Pendahuluan Kegiatan KPBU Bidang Persampahan. Kementerian Pekerjaan Umum \& Perumahan Rakyat Direktorat Jenderal Cipta Karya.

Effendi, R., Salsabila, H., \& Malik, A. (2018). Pemahaman Tentang Lingkungan Berkelanjutan. Modul vol. 18 no 2.

Elamin, M. Z., Ilmi, K. N., Tahrirah, T., Zarnuzi, Y. A., Suci, Y. C., Rahmawati, D. R., . . Nasifa, I. F. (2018). Analisis Pengelolaan Sampah pada Masyarakat Desa Disanah Kecamatan Sreseh Kabupaten Sampang. Jurnal Kesehatan Lingkungan, Vol.20, No.4.

Environement, A. Jenis dan Tipe Plastik. Retrieved from arahenvironmental.com: https://arahenvironmental.com/jenis-dan-tipe-plastik/

Hamzah, F. (2016). Retrieved from https://media.neliti.com/media/publications/267324-conflictof-waste-management-in-dki-jaka-09cdb1c8.pdf

Hendra, Y. (2016). Perbandingan Sitem Pengelolaan Sampah Di Indonesia dan Korea Selatan: Kajian 5 Aspek Pengelolaan Sampah. Retrieved from bebassampah.id: https://bebassampah.id/files/uploads/jurnal-direktorat-plp-perbandingan-sistempengelolaan-sampah-di-indonesia-dan-korea.pdf

Ibeng, P., \& Puspito, H. (2021, July 26). pendidikan.co.id. Retrieved from pendidikan.co.id: https://pendidikan.co.id/pengertian-komunitas-jenis-manfaat-contoh-menurut-para-ahli/

Mcdonough, W., \& Braungart, M. (2002). Cradle to Cradle: Remaking the Way We Make Things. North Point Press.

Jakartasatu. (n.d.). Retrieved from https://jakartasatu.jakarta.go.id

Maknun, D. (2017). Ekologi: Populasi, Komunitas, Ekosistem mewujudkan Kampus Hijau, Asri, Islami dan Ilmiah. Cirebon: Nurjati Press.

Mcdonough, W., \& Braungart, M. (2002). Cradle to Cradle: Remaking the Way We Make Things. North Point Press.

Plaza, P. I., \& Lambertucci, S. A. (2017). How are Garbage dumps impacting vertebrate demography, health, and conservation? Global Ecology and conservation .

Satmaidi, E. (2015). Konsep Deep Ecology Dalam Pengaturan Hukum Lingkungan. Jurnal Penelitian Hukum Supremasi Hukum.

Sutanto,A. (2020). Peta Metode Desain. Jakarta : Arsitektur Untar

Utomo, Y,W., Indonesia Penghasil Sampah Plastik Kedua Terbesar di Dunia? LIPI akan Buktikan Retrieved from sains.kompas.com: https://sains.kompas.com/read/2016/08/02/15373691/indonesia.penghasil.sampah.plastik. kedua.terbesar.di.dunia.lipi.akan.buktikan

Widyaningrum, G. L. (n.d.). nationalgeographic.grid.id. Retrieved from nationalgeographic.grid.id: https://nationalgeographic.grid.id/read/131244353/perilaku-manusia-dan-dampaksampah-plastik-yang-menewaskan-hewan-laut?page=all

Winahyu, D., Hartoyo, S., \& Syaukat, Y. (2013). Strategi Pengelolaan Sampah Pada Tempat Pembuangan Akhir Bantargebang, Bekasi. Jurnal Manajemen Pembangunan Daerah, Vol.5, No.2.

Winata, S. (2021). Eco-Logic.

Winnerdy, F.R., Laoda, M. Daur Ulang Plastik untuk Bahan Bangunan. Jurnal Strategi Desain \& Inovasi Sosial Volume 1 Edisi 2 April 2020

Yeang, Ken., Woo, Lillian. 2010. Dictionary of Ecodesign. New York: Routledge

Jakartasatu. (n.d.). Retrieved from https://jakartasatu.jakarta.go.id

Materi kuliah Agustinus Sutanto, DROMOS OIKOS, 4 Februari 2021 